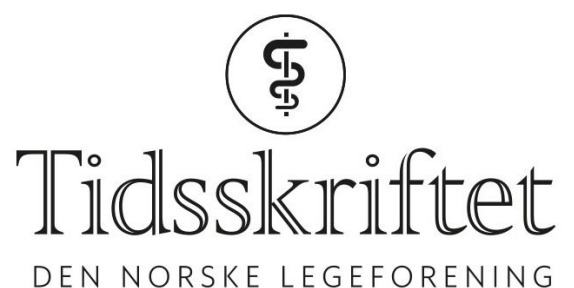

DEN NORSKE LEGEFORENING

\title{
Blødning etter tonsilleoperasjon
}

LEDER

\section{VEGARD BUGTEN}

E-post: vegard.bugten@stolav.no

Vegard Bugten er overlege ved Avdeling for øre-nese-hals, St. Olavs hospital, førsteamanuensis ved NTNU og faglig leder av Tonsilleregisteret.

Forfatteren har fylt ut ICMJE-skjemaet og oppgir ingen interessekonflikter.

Risikoen for alvorlig blødning etter tonsilleoperasjon er knyttet til operasjonsmetode og operasjonsteknikk.

Sverre Morten Zahl presenterer i Tidsskriftet en oversikt over blødningskomplikasjoner etter tonsilleoperasjoner ved Ålesund sjukehus (1). Det er gledelig å lese at komplikasjonsraten er svært lav og at få pasienter må legges inn eller reopereres.

Tonsilleregisteret ble etablert som et nasjonalt kvalitetsregister i 2017. Formålet er å kvalitetssikre behandlingen i Norge og å bidra til forskning. Tonsilleregisteret samarbeider tett med andre nordiske tonsilleregistre, med blant annet felles publisering av artikler og planlegging av videre drift av registrene (2).

I 2019 ble det gjennom forskrift om medisinske kvalitetsregistre pliktig å rapportere til nasjonale medisinske kvalitetsregistre. Dette innebærer at alle som tonsilleopereres i Norge skal spørres om de vil delta i Tonsilleregisteret. En dekningsgrad - det vil si hvor mange av de opererte som inkluderes i et register - på over 80 \% regnes som svært bra, mens denne i Tonsilleregisteret var på 65 \% 2019. Selv om man kunne ønsket seg høyere dekningsgrad, stemmer andelen reinnleggelser pga. blødninger godt med data fra Norsk pasientregister.

Tonsilleregisteret har vært i drift i fire år, og inkluderingen har økt raskt. Alle som samtykker til deltagelse får tilsendt elektronisk spørreskjema på helsenorge.no eller via andre digitale kanaler. Pasienten eller pårørende rapporterer om komplikasjoner som blødning, smerter og infeksjon direkte til registeret 30 dager etter operasjonen. Pasientene angir også om de er fornøyde med resultatet etter seks måneder. I 2019 ble det gjennomført 8572 tonsilleoperasjoner i Norge. 5587 av disse ble registrert i Tonsilleregisteret.

Gjennomsnittlig andel pasienter som ble lagt inn på grunn av seinblødning ved norske sykehus, var 7,8 \% i 2019. I årsrapporten ser man at barn blør sjeldnere enn voksne (3,9\% vs. 10,3\%), og menn blør oftere enn kvinner (16,5\% vs. 7,7\%) (3). Tilsvarende funn sees i internasjonale studier (4). Operasjonsteknikken ved tonsillektomi påvirker andelen som legges inn på grunn av postoperativ blødning. De som opererer med kalde instrumenter, har færre reinnleggelser enn de som opererer med varme instrumenter som diatermisaks, bipolar diatermipinsett og radiobølgekoblasjon. Valg av operasjonsmetode har også betydning: tonsillotomi gir mindre blødningsrisiko enn tonsillektomi (5, 6). Zahl viser at Ålesund sjukehus ligger godt under gjennomsnittet for seinblødning med bare 1,4\% 
reinnleggelser, mens 2,2 \% av pasientene hadde en tidlig blødning innen 24 timer etter operasjonen.

Tonsilleregisteret kan bidra til at alle sykehus og operatører i Norge får direkte tilbakemelding fra pasientene om komplikasjoner

Dødsfall etter tonsilleoperasjoner har forekommet i Norge og i Norden for øvrig (7). Det er derfor viktig å redusere faren for postoperativ blødning. Tonsilleregisteret har gjennomført et kvalitetsforbedringsprosjekt, der sykehus med en stor andel reinnleggelser på grunn av blødning i 2017 ble invitert til å delta. I forbindelse med prosjektet ble det tatt videoopptak av tonsilleoperasjoner utført av øre-nese-hals-kirurger fra sykehus med lav reinnleggelsesrate (8). Sykehus med høy reinnleggelsesrate fikk tilgang til videoene for bruk i internundervisning av kirurgene. Ved avslutning av prosjektet hadde gjennomsnittlig andel reinnleggelser gått ned fra $14 \%$ i 2017 til $6 \%$ i 2020 (9). Tilsvarende resultater ble observert i Sverige etter lignende tiltak (10).

Tonsilleregisteret bidrar til at alle sykehus og operatører i Norge får direkte tilbakemelding fra pasientene om komplikasjoner. Dette gir kirurgene muligheten til kontinuerlig å sjekke sine tall og eventuelt gjøre forbedringstiltak. På den måten håper vi komplikasjonsraten kan minimaliseres med tiden. Tonsilleoperasjon er meget god behandling for pasienter som plages med residiverende tonsillitter, kronisk tonsillitt og tonsillehypertrofi. I 2019 anga $92 \%$ av pasientene som besvarte spørreskjemaet, bedring av sine plager (3).

\section{LITTERATUR:}

1. Zahl SM. Seinblødning etter tonsilleoperasjon. Tidsskr Nor Legeforen 2021; 141. doi: 10.4045/tidsskr.20.0813. [CrossRef]

2. Ruohoalho J, Østvoll E, Bratt M et al. Systematic review of tonsil surgery quality registers and introduction of the Nordic Tonsil Surgery Register Collaboration. Eur Arch Otorhinolaryngol 2018; 275: 1353-63. [PubMed][CrossRef]

3. Norsk Kvalitetsregister Øre-Nese-Hals - Tonsilleregisteret. Årsrapport 2019. Trondheim: St. Olavs hospital, 2020.

https://www.kvalitetsregistre.no/sites/default/files/45xx_arsrapport_2019_tonsilleregisteret.pdf Lest 25.2.2021.

4. Coordes A, Soudry J, Hofmann VM et al. Gender-specific risk factors in post-tonsillectomy hemorrhage. Eur Arch Otorhinolaryngol 2016; 273: 4535-41. [PubMed][CrossRef]

5. Lowe D, van der Meulen J. Tonsillectomy technique as a risk factor for postoperative haemorrhage. Lancet 2004; 364: 697-702. [PubMed][CrossRef]

6. Söderman AC, Odhagen E, Ericsson E et al. Post-tonsillectomy haemorrhage rates are related to technique for dissection and for haemostasis. An analysis of 15734 patients in the National Tonsil Surgery Register in Sweden. Clin Otolaryngol 2015; 40: 248-54. [PubMed][CrossRef]

7. Østvoll E, Sunnergren O, Ericsson E et al. Mortality after tonsil surgery, a population study, covering eight years and 82,527 operations in Sweden. Eur Arch Otorhinolaryngol 2015; 272: 737-43.

[PubMed][CrossRef]

8. St. Olavs hospital. Demonstrasjonsvideoer: tonsillektomi.

https://stolav.no/fag-og-forskning/medisinske-kvalitetsregistre/norsk-tonsilleregister/kvalitetsforbedr ingsprosjekt-norsk-tonsilleregister-2018-19 Lest 25.2.2021.

9. Sluttrapport. Kvalitetsforbedringsprosjekt med bruk av data fra nasjonale medisinske kvalitetsregistre - Tonsilleregisteret. Reduksjon av antall reinnleggelser pga blødning etter tonsilleoperasjon.

https://stolav.no/seksjon/norsk-tonsilleregister/Documents/Sluttrapport\%2oKvalitetsforbedringsprosj ekter\%2oTonsilleregisteret\%2O_Sendt.pdf Lest 25.2.2021.

10. Odhagen E, Sunnergren O, Söderman AH et al. Reducing post-tonsillectomy haemorrhage rates through a quality improvement project using a Swedish National quality register: a case study. Eur 
Arch Otorhinolaryngol 2018; 275:1631-9. [PubMed][CrossRef]

Publisert: 22. mars 2021. Tidsskr Nor Legeforen. DOI: 10.4045/tidsskr.21.0127

(C) Tidsskrift for Den norske legeforening 2020. Lastet ned fra tidsskriftet.no 